\title{
AKTIVITAS ANTIMIKROBA KOMBINASI EKSTRAK PROPOLIS Trigona sp DAN JAHE (Zingiber officinale ROSCOE) TERHADAP BAKTERI Salmonella thypimurium
}

\author{
Muhammad Fadhlullah Mursalim, Abdul Wahid Jamaluddin
}

Program Studi Kedokteran Hewan Fakultas Kedokteran Universitas Hasanuddin, Makassar
Email: $\underline{\text { dullahmursalim@gmail.com }}$

\begin{abstract}
This study aims to find the antimicrobial activity of a combination of extract propolis Trigona $s p$ and gingger (Zingiber officinale var ROSCOE) against Salmonella thypimurium. The test was carried out by the method of diffusion disc with propolis and ginger test material. The study was conducted with 10 groups treatment, namely the combination of $K 1(1 \mathrm{~mL}$ ginger $(30 \%)), K 2(1 \mathrm{~mL}$ ginger (30)\% \& $1 \mathrm{~mL}$ propolis (1\%)), K3 (Ginger $1 \mathrm{~mL}(30 \%)$ \& propolis $1 \mathrm{~mL}$ (5\%), K4 (1 mL ginger (15\%)) K5 (1mL ginger (15\%) \& $1 \mathrm{~mL}$ propolis (1\%)), K6 (1 mL ginger (15\%) \& $1 \mathrm{~mL}$ propolis (5\%)), K7 (1 $\mathrm{mL}$ propolis $1 \%$ ), K8 (1 $\mathrm{mL}$ propolis 5\%), negative control K9 (DMSO 10\%), and K10 (positive control amoxicillin). The results showed that the combination extract of propolis and ginger on K3 had the highest inhibition area of Salmonella thypimurium $12.26 \mathrm{~mm}$. This study proves that various combinations of concentrations of propolis and ginger extract have antibacterial activity against the growth of Salmonella typhimurium.
\end{abstract}

Key word : Propolis Trigona sp, Zingiber officinale var ROSCOE, Salmonella typhimurium.

\section{PENDAHULUAN}

Jahe merupakan tanaman yang sangat populer di Indonesia yang banyak digunakan sebagai tanaman obat baik pada hewan dan manusia. Rimpang jahe-jahean mengandung senyawa antimikroba golongan fenol, flavonoid, terpenoid dan minyak atsiri yang terdapat pada ekstrak jahe merupakan golongan senyawa bioaktif yang dapat menghambat pertumbuhan mikroba. ${ }^{8}$ Pemanfaatan ekstrak jahe sebagai penelitian bahan antimikroba telah dilakukan di luar negeri. ${ }^{6} \quad$ Penelitian yang telah dilakukan menyatakan bahwa ekstrak tanaman jahe dengan pelarut etanol $96 \%$ dapat memberikan efek hambat terhadap pertumbuhan bakteri Strptococcus viridans $(p<0,05) .^{2}$

Propolis adalah suatu zat yang dihasilkan oleh lebah madu, karena bentuknya lengket seperti lem, disebut sebagai lem lebah. Propolis dihasilkan lebah dengan cara mengumpulkan resin atau getah dari berbagai macam tumbuhan, kemudian resin ini bercampur dengan saliva dan berbagai enzim yang ada pada lebah. ${ }^{4}$ Propolis bersifat desinfektan (antibakteri) yang dapat membunuh serangga yang masuk ke sarang lebah, lebah juga melindungi sarangnya dengan propolis dari serbuan kuman, virus atau bakteri. Hal inilah yang mendasari digunakannya propolis sebagai antibiotik. Kelebihan propolis dibanding antibiotik lainnya adalah efek sampingnya yang kecil dan tidak menimbulkan resistensi. Penelitian aktivitas antibakteri flavonoid Propolis Trigona $s p$ terhadap bakteri Streptococcus mutans (in vitro), menunjukkan propolis Trigona $s p$ secara signifikan $(p<0,05) \quad$ menghambat pertumbuhan Streptococcus mutans yang diinkubasi selama 24 dan 48 jam. $^{5}$

Infeksi paratifoid merupakan suatu penyakit pada unggas yang disebabkan oleh kelompok bakteri Salmonella thypimurium. Penyakit ini dikenal juga dengan nama 
Aktivitas antimikroba kombinasi ekstrak propolis $\underline{\text { Trigona } s p}$ dan jahe (Zingiber officinale ROSCOE) terhadap bakteri Salmonella thypimurium

salmonellosis. Paratifoid menimbulkan penyakit yang bersifat septisemic akut pada ayam muda Paratifoid ataupun infeksi pencernaan kronis pada ayam dewasa. Penyakit ini ditandai dengan adanya diare dan nekrosis fokal pada berbagai organ. ${ }^{12}$ Tujuan dari penelitian ini adalah untuk melihat aktivitas antimikroba pengaruh kombinasi ekstrak propolis dan jahe terhadap bakteri Salmonella thypimurium.

\section{METODE PENELITIAN}

\section{Alat dan Bahan}

Peralatan yang digunakan adalah toples, kain saring, mangkok, eksikator, slika gel, botol, pisau, blender, timbangan, Erlenmeyer, evaporator/ rotavapor, water bath, herbs dryer, bunsen, korek api, rak tabung, autoclave, swab, label, inkubator, mikroskop, pinset, jangka sorong, cawan petri, tabung reaksi, gelas ukur, sendok tanduk, objek glass dan ose. Bahan yang digunakan adalah isolat bakteri Escherichia coli dan salmonella $s p$ yang diperoleh dari stock culture milik Laboratorium Mikrobiologi Unhas yang diisolasi pada agar miring, Propolis, jahe, Muller Hinton Agar (MHA), aquades, paper disk,etanol $96 \%$, aluminium foil, alkohol, disk Amoksisilin, crystal violet, lugol, safranin, DMSO $10 \%$, as.sulfat, reagen (wagner, mayer, dragendorf), serbuk magnesium.

\section{Prosedur Kerja}

Seluruh alat dan bahan yang akan digunakan disterilisasi didalam autoclave selama 20 menit pada suhu sebesar $121^{\circ} \mathrm{C}$ yang sebelumnya dicuci bersih, kemudian dikeringkan dan dibungkus lalu disimpan pada sterilisator yang bersuhu $37^{\circ} \mathrm{C}$.

\section{Pembuatan Ekstrak propolis dan jahe}

Propolis yang digunakan sebanyak 1

$\mathrm{kg}$ diperoleh di kabupaten bulukumba sedangkan jahe yang kami gunakan sebanyak $20 \mathrm{~kg}$ diperoleh dari pasar tradisional di Makassar yang homogen. Kemudian dilakukan pembuatan ekstrak jahe di Klinik Hewan Pendidikan Unhas. Tahap pertama dilakukan pengeringan pada propolis dan jahe dengan metode herbs drayer. keduanya selanjutnya dibuat simplisia dengan memprosesnya menggunakan blender kering untuk menghasilkan bentuk sederhana simplisia dalam bentuk serbuk. Kemudian dimasukkan kedalam wadah dan ditambah dengan pelarut etanol $96 \%$ dengan rasio biomassa sel : pelarut adalah 1:4 (b/v). Campuran biomassa dan pelarut tersebut diekstrak dengan gelombang ultrasonik pada frekuensi $50 \mathrm{kHz}$ selama 30 menit. Hasil ekstraksi tersebut disaring dengan kain saring untuk menghilangkan ampasnya sehingga diperoleh ekstrak dengan pelarut. Untuk mendapatkan ekstrak murni, dihilangkan pelarutnya menggunakan rotary vacuum evaporator suhu $49^{\circ} \mathrm{C}$, kecepatan $20 \mathrm{rpm}$, dan tekanan 176 mBar sampai tidak ada lagi pelarut yang menetes. Tahap akhir proses ekstraksi menggunakan etanol $96 \%$ untuk mengambil konsentrasi bahan-bahan aktif. Sebelum dilakukan uji hambat antimikroba terhadap ekstrak tersebut, di lakukan uji cemaran untuk melihat ekstrak yang dibuat steril bebas dari cemaran mikroba lain. Jika terdapat mikroba akan dilakukan sterilisasi.

\section{Pembuatan Stok Bakteri}

Persiapan kultur bakteri uji bertujuan menjamin keseragaman kultur yang digunakan selama pengujian. Kultur bakteri uji terlebih dahulu dilakukan uji konfirmasi sederhana menggunakan pewarnaan Gram untuk mengetahui bakteri uji yang digunakan tidak terkontaminasi dengan bakteri lain 
Aktivitas antimikroba kombinasi ekstrak propolis $\underline{\text { Trigona } s p}$ dan jahe (Zingiber officinale ROSCOE) terhadap bakteri Salmonella thypimurium

Pewarnaan Gram digunakan untuk identifikasi anggota dari domain bakteri ke dalam dua kelompok berdasarkan perbedaan dinding selnya. Tahap pewarnaan Gram sederhana dilakukan diatas preparat kaca, yaitu kultur disebar membentuk lapisan tipis diatas preparat kaca, dikering-udarakan, dilewatkan diatas api untuk fiksasi, diwarnai dengan pewarnaan Gram, dicuci dan dikeringkan. Selanjutnya morfologi sel bakteri uji dilihat dibawah mikroskop dengan perbesaran 1.000x. Sel bakteri dengan morfologi berwarna violet merupakan bakteri Grampositif, sedangkan sel bakteri dengan

\section{HASIL DAN PEMBAHASAN}

Tabel 1. Besar daya hambat kombinasi ektrak propolis dan ekstrak jahe terhadap bakteri Salmonella typhimurium pengamatan $1 \times 24$ jam

\begin{tabular}{|c|c|c|c|}
\hline \multirow{2}{*}{$\begin{array}{l}\text { Kelompok } \\
\text { Perlakuan }\end{array}$} & \multicolumn{2}{|c|}{ Kombinasi ekstrak propolis dan jahe } & \multirow{2}{*}{$\begin{array}{c}\text { Jenis Bakteri } \\
\text { S.typhymurium }\end{array}$} \\
\hline & Jahe & Propolis & \\
\hline K1 & $1 \mathrm{~mL}(30 \%)$ & & $8 \mathrm{~mm}$ \\
\hline K2 & $1 \mathrm{~mL}(30 \%)$ & $1 \mathrm{~mL}(1 \%)$ & $7.53 \mathrm{~mm}$ \\
\hline K3 & $1 \mathrm{~mL}(30 \%)$ & $1 \mathrm{~mL}(5 \%)$ & $12.26 \mathrm{~mm}$ \\
\hline K4 & $1 \mathrm{~mL}(15 \%)$ & - & $7.53 \mathrm{~mm}$ \\
\hline K5 & $1 \mathrm{~mL}(15 \%)$ & $1 \mathrm{~mL}(1 \%)$ & $7.56 \mathrm{~mm}$ \\
\hline K6 & $1 \mathrm{~mL}(15 \%)$ & $1 \mathrm{~mL}(5 \%)$ & $7.5 \mathrm{~mm}$ \\
\hline K7 & & $1 \mathrm{~mL}(1 \%)$ & $7.16 \mathrm{~mm}$ \\
\hline K8 & & $1 \mathrm{~mL}(5 \%)$ & $7.6 \mathrm{~mm}$ \\
\hline K9 & Kontro & O 10\% & $6.93 \mathrm{~mm}$ \\
\hline K10 & Kontrol ( & illin oxoid & $40.3 \mathrm{~mm}$ \\
\hline
\end{tabular}

Hasil pengamatan diameter zona hambat menunjukkan kemampuan amoxicillin membentuk zona bening $40.3 \mathrm{~mm}$ untuk bakteri Salmonella thypimurium. Sedangkan zona bening yang terbentuk pada kombinasi ekstrak propolis dan jahe bervariasi tergantung kombinasi konsentrasi ekstrak. Untuk kelompok pertama dimana $1 \mathrm{~mL}$ (30\%) ekstrak jahe menunjukkan zona bening $8 \mathrm{~mm}$ untuk bakteri Salmonella thypimurium. Kelompok 2 dimana kombinasi ekstrak $1 \mathrm{~mL}$ (30\%) ekstrak jahe dan $1 \mathrm{~mL}(1 \%)$ ekstrak morfologi berwarna merah merupakan bakteri Gram-negatif. ${ }^{9}$ Pembuatan stok bakteri ini dilakukan untuk memperbanyak bakteri, dengan cara menginokulasikan 1 ose biakan murni bakteri Salmonella thypimurium dalam media MHA (Muller Hilton Agar), kemudian diinkubasi selama 24 jam dengan suhu $37^{\circ} \mathrm{C}$ di dalam inkubator). Daya Hambat diketahui berdasarkan pengukuran diameter zona inhibisi (zona bening atau daerah jernih tanpa pertumbuhan mikroorganisme yang terbentuk disekitar koloni setelah diberikan paper disk yang berisi ekstrak. Pengukuran tersebut menggunakan jangka sorong. 
Aktivitas antimikroba kombinasi ekstrak propolis $\underline{\text { Trigona } s p}$ dan jahe (Zingiber officinale ROSCOE) terhadap bakteri Salmonella thypimurium

terhadap bakteri Salmonella thypimurium. Kelompok 6 kombinasi ekstrak jahe $1 \mathrm{~mL}$ (15\%) dan $1 \mathrm{~mL}$ (5\%) menunjukkan zona bening $7.5 \mathrm{~mm}$ untuk bakteri Salmonella thypimurium. Kelompok 7 ekstrak propolis 1 $\mathrm{mL}(1 \%)$ menunjukkan zona bening untuk Salmonella thypimurium $7.16 \mathrm{~mm}$. Kelompok 8 menunjukkan ekstrak propolis $1 \mathrm{~mL}(5 \%)$ menunjukkan zona bening $7.6 \mathrm{~mm}$ umtuk Salmonella thypimurium.

Ekstrak jahe segar dapat menghambat uji pertumbuhan mikroba dengan memvariasikan diameter zona hambat. Ini karena ekstrak jahe segar memiliki senyawa anti-mikroba. ekstrak jahe segar mengandung beberapa komponen minyak atsiri yang terdiri dari $\alpha$-pinena, kamfena, kariofilena, $\beta$-pinena, $\alpha$-farnesene, cineol, dlkamfor, isokariofilena, kariofilena-oxide, dan germacron yang dapat menghasilkan antimikroba untuk menghambat pertumbuhan mikroba. ${ }^{10}$ Rimpang jahe memiliki senyawa antimikroba di kelas fenol, flavonoid, terpenoid dan minyak atsiri yang ditemukan dalam ekstrak jahe adalah kelompok senyawa bioaktif yang dapat menghambat pertumbuhan mikroba. ${ }^{8}$ Kandungan flavonoid dalam propolis memiliki aktivitas antibakteri melalui hambatan fungsi DNA bakteri yang mengakibatkan replikasi bakteri dan kemampuan translasi terhambat. Aktivitas biologis flavonoid dalam propolis terhadap bakteri dilakukan dengan merusak membran sitoplasma bakteri.

Penelitian yang telah dilakukan menyebutkan bahwa propolis memiliki efek antibakteri pada Staphylococcus aureus, Escherichia coli, dan Candida albicans, efek anti-bakteri propolis bervariasi dan tergantung pada daerah asal propolis. ${ }^{3}$ Efek antimikroba yang disebabkan oleh propolis dengan mencegah pembelahan sel, dan propolis juga dapat merusak membran sitoplasma dan dinding sel yang menyebabkan bakteriolisis parsial dan menghambat sintesis protein. Mekanisme kerja propolis sangat kompleks sehingga tidak dapat dibuat sebagai bentuk klasik antibiotik. $^{13}$

Penelitian sebelumnya menyebutkan bahwa pada uji penghambatan ekstrak Trigona sp propolis terhadap bakteri Escherichia coli menunjukkan bahwa semakin kecil konsentrasi, semakin rendah penghambatan bakteri ${ }^{11}$ dan ekstrak Apis mellifera propolis dapat menghambat bakteri Staphylococcus aureus dan Bacillus subtilis pada konsentrasi $5 \%{ }^{7}$ Kombinasi ekstrak propolis dan jahe yang menunjukkan diameter zona hambat terbesar adalah kelompok ketiga di mana kombinasi ekstrak jahe $1 \mathrm{~mL}(30 \%)$ dan ekstrak propolis $1 \mathrm{~mL}(5 \%)$ menunjukkan zona bening sebesar 12,26 $\mathrm{mm}$ untuk Salmonella thypimurium.

Respon penghambatan kombinasi propolis dan ekstrak jahe terhadap uji mikroba berdasarkan kategori penghambata adalah sebagai berikut: diameter zona hambat $\leq 10$ $\mathrm{mm}$ dikatakan tidak menghambat uji mikroba pertumbuhan $(\mathrm{T})$, diameter 11-15 $\mathrm{mm}$ dikategorikan lemah (L), diameter 16-20 mm dikategorikan sedang (S), dan diameter> 20 mm dikategorikan kuat $(\mathrm{K}){ }^{1}$

\section{KESIMPULAN}

Berdasarkan hasil penelitian ini dapat disimpulkan yakni setelah inkubasi selama 24 jam semua kombinasi ekstrak yang diuji mampu menghambat pertumbuhan Salmonella thypimurium.

\section{DAFTAR PUSTAKA}

1. Greenwood. Antibiotics Susceptibility (Sensitivity) Test, Antimicrobial and 
Aktivitas antimikroba kombinasi ekstrak propolis $\underline{\text { Trigona } s p}$ dan jahe (Zingiber officinale ROSCOE) terhadap bakteri Salmonella thypimurium

Chemotheraphy. United State of America: Mc Graw Hill Company. 1995.

2. Hanief S. Efektivitas Ekstrak Jahe ( Zingiber officinale ROSCOE) Terhadap Pertumbuhan Bakteri Streptococcus viridans. Jurnal Universitas Islam Negeri Syarif Hidayatullah. 2013. 1-61 p.

3. Hegazi AG, Abd El Hady FK. Chemical and biological studies of Egyptian propolis. In: International Symposium On Apitherapy. 1997.

4. Lofty M. Biological activity of bee propolis in health and disease. Asian Pacific Journal of Cancer Prevention. 2006; Vol 7:22-31.

5. Sabir A. Aktivitas antibakteri flavonoid propolis Trigona $\mathrm{sp}$ terhadap bakteri Streptococcus mutans (In Vitro). Maj Ked Gigi. 2005;38(3):135-41.

6. Singh G, Kapoor IP, Singh $P$, de Heluani CS, de Lampasona MP, Catalan CA. Chemistry, antioxidant and antimicrobial investigations on essential oil and oleoresins of Zingiber officinale. Food Chem Toxicol. 2008;46(10):3295-302.

7. Novilla A. Aktivitas antibakteri ekstrak propolis Apis mellifera terhadap pertumbuhan Methicillin-Resistant Staphylococcus aureus (MRSA) secara in vitro. Jurnal Kesehatan Kartika Stikes A. Yani. 2010; 9-16.

8. Nursal W, Sri dan Wilda S. Bioaktifitas ekstrak jahe (Zingiber officinale Roxb.) dalam menghambat pertumbuhan koloni bakteri Escherichia coli dan Bacillus subtilis. Jurnal Biogenesis, 2006;2 (2): 6466.

9. Madigan MT, Martinko JM, Parker J. Brock Biology of Microorganisms Tenth Edition. USA: Prentice Hall Inc, 2003.

10. Mulyani S. Komponen dan Anti-bakteri dari Fraksi Kristal Minyak Zingiber zerumbet. Majalah Farmasi Indonesia, 2010;21(3):178-184.

11. Prasetyorini, Hasan AEZ, Siregar R. Penerapan teknologi nanopartikel propolis Trigona spp asal Bogor sebagai antibakteri Eschericia coli secara in vitro. Ekologia, 2011;11(1):36-43.

12. Tabbu. Penyakit ayam dan penanggulangannya volume 1 . Yogyakarta : Penerbit Kanisius, 2000.

13. Takaisi-Kikuni NB, Schilcher H. Electron microscopic and microcalorimetric investigations of the possible mechanism of the antibacterial action of a defined propolis provenance. Planta Med. 1994;60(3):222-7. 